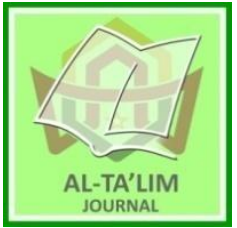

AL-TA'LIM JOURNAL, 26 (2), 2019, (121-130)

(Print ISSN 1410-7546 Online ISSN 2355-7893)

Available online at http://journal.tarbiyahiainib.ac.id/index.php/attalim

\title{
The Development of Teaching Materials on Integrated Science, Technology, and Religion to Improve College Students' Integrative Knowledge
}

Received: $05^{\text {th }}$ October 2018; Revised: $28^{\text {th }}$ May 2019; Accepted: $30^{\text {th }}$ July 2019

Permalink/DOI: http://dx.doi.org/10.15548/jt.v26i2.532

\section{Muhammad Nasir*)}

Institut Agama Islam Negeri Palangka Raya, Indonesia

E-mail: nasir@iain-palangkaraya.ac.id

\section{Hadma Yuliani}

Institut Agama Islam Negeri Palangka Raya, Indonesia

E-mail: hadma.yuliani@iain-palangkaraya.ac.id

\section{Luvia Ranggi Nastiti}

Institut Agama Islam Negeri Palangka Raya, Indonesia

E-mail: luviaranggi@gmail.com

*) Corresponding Author

\begin{abstract}
The purposes of this study were (1) to determine the specifications of teaching materials integrated STR; and (2) to analyze the results of expert validation to teaching materials integrated STR. The research method used in this study was Research and Development (R \& D) with a four-D procedure (Define, Design, Develop, and Disseminate). The data analysis technique used was descriptive analysis techniques. The results of the study show that (1) The profile of the teaching materials integrated STR are (a) teaching materials are integration between concepts of fundamental of physics and Islamic values of Al-Quran and Hadith; and (b) the media developed is an integration between PPT and Phet; and (2) The results of the material expert validation on the results of the development of teaching materials integrated STR on aspects of content feasibility, aspects of presentation, aspects of language, and material integration are well categorized. Likewise, the results of media expert validation on the display and programming aspects show good categories
\end{abstract}

Keywords: integrative teaching materials; science; technology; religion.

How to Cite: Nasir, M., Yuliani, H., \& Nastiti, L. (2019). The development of teaching materials on integrated science, technology, and religion to improve college students' integrative knowledge. Al-Ta Lim Journal, 26(2). doi:http://dx.doi.org/10.15548/jt.v26i2.532

\section{INTRODUCTION}

Physics Education Study Program graduates in state Islamic Universities must have an Islamic personality and have a scientific paradigm of integration between science and religion (Rijal, 2015; Yunus, 2014). In line with that, Suprayogo (2017) revealed that Islamic university graduates have at least four strengths, namely: (1) robustness of aqeedah and spiritual depth, (2) moral majesty, (3) breadth of knowledge and (4) professional maturity. To address this, every Islamic tertiary institution in Indonesia has formulated the concept of integration which is implemented in the form of curricula and integrative learning processes (Rifai, Fauzan, \& Bahrissalim, 2014). In Islam, the use of modern technology is encouraged as it helps towards the development of positive thinking, the ability to innovate and to trigger the drive for self-improvement (Lubis, 2015; Lubis \& Wekke, 2009).

In twenty-first century, personal success lies in being able to communicate, 
share, and use information to solve complex problems, in being able to adapt and innovate in response to new demands and changing circumstances, in being able to marshal and expand the power of technology to create new knowledge, and in expanding human capacity and productivity (Binkley et al., 2012). Teachers in the twenty-first century, in all educational sectors, have to cope with an everchanging cultural and technological environment (Laurillard, 2013a, 2013b). According to education experts, to be successful in the world of work in the 21 st century, a lifetime students must learn about high, flexible, integrative and adaptive spending as well as a blend of both knowledge and skills (Lan \& Macapat, n.d.; Milic, 2013; Wang, Wong, \& Lu, 2001). Therefore, information communication technology literacy (ICT) really needs to be integrated into learning. The role of ICT in education is becoming more and more important and this importance will continue to grow and develop in the 21st century (Sarkar, 2012). Besides that the importance of a structured approach to planning technology integration to support preserves teachers (Hutchison \& Colwell, 2016). Factors that influence the ability of teachers to implement ICT-based learning are lack of teacher ICT skills; lack of teacher confidence; lack of pedagogical teacher training; 1 lack of suitable educational software; limited access to ICT; the rigid structure of traditional education systems; restrictive curricula (BuabengAndoh, 2012).

In order for the technology to be synchronized with learning, the technology should be integrated into the learning system through the following stages: (1) determine relative benefits, (2) set goals and assessments, (3) design and integration strategy, (4) preparing instructional conditions; and (5) evaluation and improvement of integration strategies. Integrative learning is seen as an effective learning approach for developing knowledge, skills and building the character of students (Sari \& Syamsi, 2015). In line with this, (Abidin, 2014) mentions several advantages of integrative learning, namely (1) integrative learning can develop the ability of students to understand a concept multi-perspective, (2) integrative learning fosters soft skills and hard skills so as to be able to equip skills the lives of students in everyday life, (3) effective integrative learning to develop the character of students and make students in accordance with the expectations of the community, namely intelligent, creative, innovative, and character, (4) integrative learning develops logical thinking skills, systematic, and scientific, (5) integrative learning is able to be the best solution for developing learning processes that are motivational, interesting, and fun.

Integrative learning can be done well if an educational unit has implemented an integrated curriculum. According to (Drake, 2007), the realization of an integrated curriculum can be done in several ways, namely (1) fusion of several topics into one; (2) incorporating scientific sub-discipline into its parent into one unit (within one subject); (3) connecting one topic with other knowledge that is being studied by students but different hours (multidisciplinary); (4) study one topic by using various perspectives at the same time (interdisciplinary); and (5) linking a topic with current values, events, issues (transdisciplinary). The implementation of an integrated curriculum at IAIN Palangka Raya was taken by providing proportional Islamic courses with a subject in the Physics Education Study Program. Islamic courses and expertise courses in physics education courses are taught separately. In the IAIN Palangka Raya, Physics education curriculum is no specific subject that studies the integration of physics with Islamic sciences. Integration in the learning process is carried out in a dialogical way, namely linking concepts learned with verses from the Qur'an or hadith related to the concepts of physics being studied. In addition, teaching materials that have not been formulated integrated manner between physics skills courses with Islamic values have yet to be found, but the integration between science and Islam is found in semester lecture plans that include 
verses of the Qur'an and hadith relating to subject matter that will be taught.

Effective teaching has consistently identified strong content knowledge as an essential element (Stronge, 2018). However, ICT integration is limited to a few specific resources (mainly computers and projectors), mostly applied to perform "traditional" pedagogical activities (Brun \& Hinostroza, 2014). Conceptions of integrated STEM (Science, Technology, Engineering, and Mathematics) and the frameworks that guided the curriculum development process play a significant role in what teachers decide to include and emphasize in units they create (Ring-Whalen, Dare, Roehrig, Titu, \& Crotty, 2018). Multidisciplinarity and interdisciplinarity are a common practice among strict sciences and technologies (Alvargonzález, 2011). In this study, technology was integrated as a medium to integrate the concepts of science and religion. This integration model is referred to by (Fogarty \& Pete, 2009) as a threaded model that is integrating what is thought with cognitive tools, strategies, and technical tools that cross disciplines. Through media, simulation can be performed best on understanding the concept (Eskrootchi \& Oskrochi, 2010).

Based on these conditions, it is necessary to develop integrative teaching materials used in learning. The results of the Fardiana (2015) study show that the development of Islamic integration-based thematic textbooks fulfills the valid criteria of $88 \%$ media experts and $92 \%$ material experts. (Wastyanti, 2016) shows that multimediabased science and religion integration teaching materials produced have a high level of effectiveness and attractiveness. This is indicated by the results of the trials in the good category. Given the concept of integration is not only done in the realm of material but also the realm of strategy so that researchers are interested in developing teaching materials STR (Science, Technology, and Religion). In the realm of material will be integrated the concepts of physics and Islamic values contained in the Qur'an and Hadith while in the realm of media will be developed PPT integrated with PhET. PhET is a simulation application based on the Java Interface programming language (Neri, Noguez, Pérez, \& Aguilar, 2011). PhET can be used offline or online. in addition, PhET provides hundreds of millions of scientific trial simulations that have been uploaded in the PhET database and can be downloaded freely. Through this integrated media, students are expected to easily understand the integration of physics concepts and Islamic values through Phet's visualization. Through visualization, abstract mathematical concepts and equations can be concretized (Mahnun, 2012). The purpose of this development research is (1) to find out the specifications of the STR integrative teaching material; and (2) to find out the results of expert validation of integrative STR teaching materials.

\section{METHOD}

This research method is a research and development $(\mathrm{R} \& \mathrm{D})$ method. The procedure for the development of integrated integrative teaching materials follows the four $\mathrm{D}$ development model by Lim \& Chai (2008). This model consists of four stages, namely define, design, develop, and disseminate. The define phase consists of Front end analysis, learner analysis, task analysis, concept analysis, and specifying instructional objectives. The design phase consists of constructing criterion-referenced tests, media selection, format selection, initial design. The develop phase consists of expert appraisal and developmental testing. The disseminate stage consists of validation testing, packaging, diffusion, and adoption. In this study, it was carried out only until limited validation testing that is on material and media expert.

\section{RESULT AND DISCUSSION}

The results of the research obtained at each stage of development can be explained as follows. 


\section{Define Stage}

In this stage, conducted several steps that are front end analysis, learners analysis, task analysis, concept analysis, and specifying instructional objectives. The front end analysis aims to bring up and determine the basic problems faced in physics learning so that the development of learning materials is needed. The front end analysis was carried out through observing the conditions of the teaching material of the Palangka Raya IAIN physics education study program, literature study, and determining the subject matter of the development of teaching materials. Documentation study conducted at the physics education study program of State Islamic Institute of Palangka Raya. There was no available teaching material integrated STR so it was necessary to develop teaching materials integrated STR in the physics education study program of State Islamic Institute of Palangka Raya.

Learner analysis carried out to determine the background of students, students' initial knowledge and experience of students in conducting integrative learning with materials integrated STR. Analysis of students as product testing site has been determined by students in the first semester of Biology Education who take fundamental of physics course. This is done by considering that there are many concepts in basic physics that can be integrated with Islamic values and easily understood by students. Task analysis is carried out to detail the contents of teaching materials which include content structure analysis, procedural analysis, and analysis of information processing processes in teaching materials integrated STR. Information processed by direct learning using PPT integrated by Phet. Concept analysis is the identification of the main concepts that are targeted to be understood by students systematically. The steps taken are (1) Identifying basic competencies of fundamental of physics and verses of AlQur'an Interpretations; (2) Describing basic competence into indicators; and (3) Identifying concepts that can be combined with the verses of the Qur'an . The results of the analysis of the basic physics concepts and interpretations of the verses of the Qur'an are (1) the relationship between the concepts of straight motion with straight path interpretations in Surah Al Fatihah verse 6 and Surah An Nahl verse 9; (2) the relation between the concept of acceleration and interpretation of Surah Al Baqarah verse 148; (3) the relationship between the concept of circular motion and the interpretation of Surah Al Anbiya verse 33 and surah Yaasin verse 38; (4) the relationship between the Newton I law and the interpretation of Surah Ar Ra'd verse II; (5) the relevance of Newton's second law concept with the interpretation of Surah Al Jatsiyah verse 22; (6) the connection of the concept of Newton III Law with the interpretation of Surah $\mathrm{Ar}$ Rahman verse 60 . The results of the concept analysis are then poured in the form of concept maps of the integration of science and religion.

The activity carried out in specifying instructional objectives is to formulate learning objectives that are student integrative knowledge, namely the ability of students to integrate physics concepts with Islamic values in the Qur'an and Hadith. The formulation of learning objectives in this study include (1) students are able to combine the concepts of straight motion with interpretations of the straight path in Surah Al Fatihah verse 6 and Surah An Nahl verse 9; (2) students are able to combine the concepts of acceleration and interpretation of Surah Al Baqarah verse 148; (3) students are able to combine the concept of circular motion with the interpretation of Surah Al Anbiya verse 33 and surah Yaasin verse 38 ; (4) students are able to combine the Newton I law concept and the interpretation of Surah Ar ra'd verse 11; (5) students are able to integrate Newton's II legal concepts with the interpretation of Surah Al Jatsiyah verse 22 ; (6) students are able to combine the concepts of Newton III Law with the interpretation of Surah Ar Rahman verse 60. 


\section{Design Stage}

In this stage conducted several steps that are constructing a criterion-referenced test, media selection, format selection, and initial design. To measure the achievement of integrative learning in teaching materials that have been developed, a test of integrative knowledge test is made. The questions made are developed from the learning objectives that have been set. In addition to integrating basic physics material and interpretation of the verses of the Qur'an , media integration was also carried out in the delivery of learning. Media integration in this research is the integration of Phet technology in Power Point. The evaluation menu of integrative knowledge can facilitate students to practice integrating physics concepts with Islamic values. Evaluation of learning outcomes is intended to facilitate students to strengthen their understanding of the concepts that they have learned.

\section{Develop Stage}

Validation of the teaching material integrated STR has carried out through two stages, namely validation by material experts and validation by media experts. Aspects assessed on the integration of science and religion material in teaching materials include aspects of content feasibility, presentation feasibility, language feasibility, and material integration. The results of the development of the material aspect are in Table 1.

Table 1. Results of Expert Validation on Material Integration of Science and Religion

\begin{tabular}{|c|c|c|c|c|}
\hline No & Aspect & Indicator & Score & Criteria \\
\hline \multirow[t]{5}{*}{1} & Content & Conformity of material with basic competence & 3.5 & Good \\
\hline & Feasibility & Material accuracy & 3 & Good \\
\hline & & Material update & 2.5 & $\begin{array}{l}\text { Pretty } \\
\text { good }\end{array}$ \\
\hline & & Encourage curiosity & 3 & \\
\hline & & Mean & 3 & Good \\
\hline \multirow[t]{5}{*}{2} & Feasibility of & Presentation technique & 3 & Good \\
\hline & Presentation & Support presentation & 2.8 & $\begin{array}{l}\text { Pretty } \\
\text { good }\end{array}$ \\
\hline & & Learning presentation & 3.5 & Good \\
\hline & & Coherence and impulse flow of thinking & 3.5 & Good \\
\hline & & Mean & 3.2 & Good \\
\hline \multirow[t]{6}{*}{3} & Feasibility of & Straightforward & 3 & Good \\
\hline & Language & Communicative & 3 & Good \\
\hline & & Dialogical and Interactive & 3 & Good \\
\hline & & Conformity with Development & 3 & Good \\
\hline & & Learners & 3 & Good \\
\hline & & Mean & 3 & Good \\
\hline \multirow[t]{6}{*}{4} & $\begin{array}{l}\text { Integrative } \\
\text { Material }\end{array}$ & $\begin{array}{l}\text { Able to combine the concept of straight motion with a straight way } \\
\text { interpretation in Surah Al Fatihah } \\
\text { verse } 6 \text { and Surah An Nahl verse } 9\end{array}$ & 3 & \\
\hline & & $\begin{array}{l}\text { Able to combine the concept of acceleration with the interpretation of } \\
\text { Surah Al Baqarah verse } 148\end{array}$ & 3 & Good \\
\hline & & $\begin{array}{l}\text { Able to combine the concept of circular motion with the interpretation of } \\
\text { Surah Al Anbiya verse } 33 \text { and Surah Yaasin verse } 38 .\end{array}$ & 3 & Good \\
\hline & & $\begin{array}{l}\text { Able to combine the concept of Newton I law with the interpretation of } \\
\text { Surah Ar Ra'd verse II }\end{array}$ & 3 & Good \\
\hline & & $\begin{array}{l}\text { Able to combine Newton III Law concepts with the interpretation of } \\
\text { Surah Ar Rahman verse } 60\end{array}$ & 3 & Good \\
\hline & & Mean & 3 & Good \\
\hline
\end{tabular}


Table 2. The results of expert validation of integrated Phet on PPT

\begin{tabular}{lllll}
\hline No & Aspect & Indicator & Score & Criteria \\
\hline 1 & Display & Text or writing readability & 3 & Good \\
& $\begin{array}{l}\text { Distance settings: lines, paragraphs, } \\
\text { boundaries, and characters }\end{array}$ & 3 & Good \\
& $\begin{array}{l}\text { Selection of type and size of letters } \\
\text { Coloring, drawing, writing, and chart }\end{array}$ & 2.5 & Pretty good \\
& Image placement & 3 & Good \\
& Animation settings & 3 & Good \\
& Layout (layout) & 3.5 & Good \\
& Slide design & 3 & Good \\
& Selection background & 3.5 & Good \\
& Balance the level of monitor resolution with & 2.8 & Good \\
& the product & 3 & Pretty good \\
& Product exterior design (cover) & 3 & Good \\
& $\quad$ Mean & 3.03 & Good \\
& Interaction optimization & 2.5 & Pretty good \\
& Ease of navigation & 3.5 & Good \\
& Freedom to choose menus to learn & 3.5 & Good \\
& Composition of each slide & 3 & Good \\
& Operating system compatibility & 3 & Good \\
& Ease of use & 3 & Good \\
& Sound background choice & 3 & Good \\
& Program speed & 3 & Good \\
& The software can be run & 3.05 & Good \\
& & & Good \\
\hline
\end{tabular}

Profile of teaching materials integrated STR that has been made are (1) teaching materials developed are teaching materials that integrate the concepts of fundamental of physics and interpretation of the verses of the Qur'an and hadith. This integration is done by identifying skills, concepts, and attitudes that can be integrated. The advantage of this method is to encourage students to see both interrelationships between two disciplines; (2) $\mathrm{PhET}$ and Power Point media integration. Media integration is done to facilitate the accessibility of students to analyze the fundamental of physics concepts and interpretations of the verses of the Qur'an and hadith in one media through simulation and visualization. Rahma's research results, (2018) has produced integrative Islamic teaching materials with specifications (a) The main presentation in the product development of character-based integrative thematic teaching materials with multimedia in the form of Adobe Flash consists of (1) opening page; (2) the main menu page consists of instructions, objectives, material, my activities, evaluation, and profile of the developer; (b) The main product offering for the development of character-based integrative thematic teaching materials with interactive multimedia in the form of print media for student worksheets is (1) The front (front cover); (2) The opening part which consists of student identity, introduction, character identification, table of contents, and core competencies; (3) The content section which consists of the title of the sub-theme, opens insight, let's write, let's listen, let's sing, and let's observe; (4) Closing section, namely bibliography, developer profile; (5) Back cover. In addition, Winarti (2017) has developed teaching materials with the title development of learning devices with integration Islamic and science with results of data analysis showing that the learning tools that have been developed are considered very 
good and feasible to use as teaching materials in temperature and heat learning.

The equality of this study with the above research is to jointly develop teaching materials integrated with science and Islamic values. The difference is in this development, in addition to developing integrated material but also developing PPT media integration with Phet technology in learning so that the material that has been developed becomes more interesting and makes it easier for students to understand the concept of integration of science and technology.

\section{Validation of STR Teaching Materials}

Based on Table 4.1 above, it was found that the feasibility aspects of the content, aspects of presentation, language aspects, and integrative material were in good categories. In terms of material accuracy, material updating, and encouraging the need for knowledge need to be improved, if it is seen from the result of validation.

In addition, the aspects of presentation techniques in terms of supporting the presentation and presentation of learning also need to be improved. While the feasibility aspects in terms of straightforward, communicative, interactive dialogue, conformity with student development, and conformity with the rules of Indonesian language have met the standard (in good category). Besides that the integrative aspects of the material also meet the standards, in this case, are (1) combining the concept of straight motion with interpretations of the straight path in Surah Al Fatihah verse 6 and Surah An Nahl verse 9; (2) combining the concept of acceleration with the interpretation of Surah Al Baqarah verse 148; (3) combining the concept of circular motion with the interpretation of Surah Al Anbiya verse 33 and Surah Yaasin verse 38; (4) integrating the concept of Newton I law with the interpretation of Surah Ar ra'd verse II; and (5) integrating the concept of Newton III Law with the interpretation of Surah Ar Rahman verse 60 .
Based on table 4.2 it can be seen that the results of the validation test on the integration of technology media Phet on the PPT integrative teaching materials STR received good perceptions from media experts, both for the display and programming aspects, where the average score for the display aspect was 3.02 and programming aspects is 3.05. On the display aspect, the indicator that gets the highest perception score is the animation setting indicator (3.5) and the slide display indicator (3.5). While on the programming aspect, indicators that get the highest perception are ease of navigation indicators (3.5) and menu freedom indicators to learn (3.5).

Development in terms of material morality and material accuracy, researchers feel the difficulty because it is caused by a concept that is integrated is basic physics which are basic concepts not the concept of applied physics which continues to evolve at any time, as well as verse interpretations based solely on the interpreters who interpret the verse in ancient times. Researchers can only synthesize the relationship between basic physics concepts and verse interpretations that have citation sentences that make it possible to find a common thread of meaning that can be integrated.

The validator's comments on instructional materials have not spurred the readers' sense of desire because this teaching material does not contain scientific activities to verify the truth of the integration of the concepts. Because of the paradigm between science and religion is different, where science is based on empirical data obtained from scientific methods while religion is normatively based on revelation so that researcher found it is difficult to integrate the two paradigms in scientific activities. This is in line with the results of the study Sherkat (2011) that said sectarian Protestants, Catholics, and people with fundamentalist beliefs in the inerrancy of the Bible have significantly lower levels of scientific literacy when compared with secular Americans. In addition, in the matter of integrative knowledge, 
there is no matter of count and the development of concepts into new situations such as cognitive abilities. Thus they only need the ability to think logically and analytically.

According to the validator, language and integrative aspects of the material have standardized because the selected verse contains sentences relating to the concept of fundamental of physics. Integration efforts are carried out in terms of how to connect physical quantities into a normative value that can motivate the reader to make improvements and goodness based on the principle of natural law (kauniyah) which the concept has been revealed in the realm of Aya Al-Qur'an . Thus the impulse that arises in the reader is derived from kauniyah rational and normative transcendental rabbaniyah so that the reader has an innovative understanding in learning science.

The superiority of the teaching material integrated STR is that it can facilitate students to understand the integration of physical concepts and Islamic values based on the Qur'an and Hadith visually. This visualization makes it easy to synthesize relationships between integrated concepts. This intensive learning can help students to obtain holistic and integrative knowledge between science and religion. Fatchurrohman (2014) said that the benefits of integrative thematic learning, namely: (1) eliminate overlapping teaching materials; (2) students understand meaningful relationships between subjects; (3) learning to be intact by students will get an understanding of concepts and material that is not fragmented; (4) mastery of concepts by students will improve. Integrative thematic learning can help students to have knowledge that is meaningful and interrelated, students are trained to think comprehensively, look at things from various points of view. In the end, students will have a broad and deep insight into science that is interrelated and can create a learning system that is very loaded with Islamic values (Lubis, 2015; Muspiroh, 2014). In addition, the integrative knowledge competence framework can provide practitioners with useful guidance on what the key knowledge determinants are and how the relationships between knowledge components should be best managed to achieve success in real life situations (Jayawickrama, Liu, \& Smith, 2016).

\section{CONCLUSION AND RECOMMENDATION}

Based on the results and discussion, several conclusions can be synthesized: (1) The profile of the teaching materials integrated STR that have been made are (a) the teaching material contains the integration of concepts of fundamental of physics and Islamic values sourced from Al-Qur'an and Hadith ; and (b) the media developed is an integration between PPT and Phet which aims to visualize the concept of integration concepts of fundamental of physics material and Islamic values originating from AlQur'an and Hadith; and (2) the results of material expert validation on the results of the development of teaching materials integrated STR on both aspects material and media are good.

This research certainly still has many shortcomings in terms of both the development stage and the trial results. Especially in terms of trials, these teaching materials have only been tested in a limited way so that more extensive trials are needed and carried out repeatedly to get better product development results. In this study, in terms of media integration, it is done in the form of Phet integration on PPT. for subsequent research it is necessary to integrate fully between material and several of ICT media.

\section{REFERENCES}
Abidin, Y. (2014). Desain sistem pembelajaran dalam konteks kurikulum 2013. Refika Aditama.

Alvargonzález, D. (2011). Multidisciplinarity, interdisciplinarity, transdisciplinarity, and the sciences. International Studies in the Philosophy of Science, 25(4), 387-403. 
Binkley, M., Erstad, O., Herman, J., Raizen, S., Ripley, M., Miller-Ricci, M., \& Rumble, M. (2012). Defining twentyfirst century skills. In Assessment and teaching of 21st century skills (pp. 1766). Springer.

Brun, M., \& Hinostroza, J. E. (2014). Learning to become a teacher in the 21 st century: ICT integration in Initial Teacher Education in Chile. Journal of Educational Technology \& Society, 17(3), 222-238.

Buabeng-Andoh, C. (2012). Factors influencing teachersâ adoption and integration of information and communication technology into teaching: A review of the literature. International Journal of Education and Development Using ICT, 8(1).

Drake, S. M. (2007). Creating StandardsBased Integrated Curriculum: Aligning Curriculum, Content, Assessment, and Instruction. ERIC.

Eskrootchi, R., \& Oskrochi, G. R. (2010). A study of the efficacy of project-based learning integrated with computerbased simulation-S ${ }^{\text {TELLA. Educational }}$ Technology \& Society, 13(1), 236245.

Fardiana, I. U. (2015). Pengembangan media pembelajaran ilmu pengetahuan alam berbasis integrasi sains dan Islam pada kelas IV MI Mamba'ul Huda Ngabar Ponorogo. Qalamuna-Jurnal Pendidikan, Sosial, Dan Agama, 7(1), 73-93.

Fatchurrohman, F. (2014). Pembelajaran Tematik Integratif Konsep Dasar dan Aplikasi. IAIN Salatiga press.

Fogarty, R. J., \& Pete, B. M. (2009). How to integrate the curricula. Corwin Press.

Hutchison, A., \& Colwell, J. (2016). Preservice Teachers' Use of the
Technology Integration Planning Cycle to Integrate iPads Into Literacy Instruction. Journal of Research on Technology in Education, 48(1), 1-15.

Jayawickrama, U., Liu, S., \& Smith, M. H. (2016). Empirical evidence of an integrative knowledge competence framework for ERP systems implementation in UK industries. Computers in Industry, 82, 205-223.

Lan, T. D., \& Macapat, T. (n.d.). Sumber belajar penunjang PLPG 2017 mata pelajaran/paket keahlian Bahasa Jawa.

Laurillard, D. (2013a). Rethinking university teaching: A conversational framework for the effective use of learning technologies. Routledge.

Laurillard, D. (2013b). Teaching as a design science: Building pedagogical patterns for learning and technology. Routledge.

Lim, C. P., \& Chai, C. S. (2008). Rethinking classroom-oriented instructional development models to mediate instructional planning in technologyenhanced learning environments. Teaching and Teacher Education, 24(8), 2002-2013.

Lubis, M. A. (2015). Effective implementation of the integrated Islamic education. Global Journal AlThaqafah, 5(1), 59-68.

Lubis, M. A., \& Wekke, I. S. (2009). Integrated Islamic education in Brunei Darussalam: The hopes and challenges. Educare, 1(2).

Milic, S. (2013). The twenty-first century university and the concept of lifelong learning. Australian Journal of Adult Learning, 53(1), 151-170. 
Muspiroh, N. (2014). Integrasi Nilai-Nilai Islam dalam Pembelajaran IPA di Sekolah. Quality, 2(1), 168-188.

Rifai, N., Fauzan, F., \& Bahrissalim, B. (2014). Integrasi keilmuan dalam pengembangan kurikulum di uin seindonesia: Evaluasi penerapan integrasi keilmuan uin dalam kurikulum dan proses pembelajaran. Tarbiya: Journal of Education in Muslim Society, 1(1), 13-34.

Rijal, A. S. (2015). Urgensi pendidikan integratif-nondikotomik di perguruan tinggi Islam. TADRIS: Jurnal Pendidikan Islam, 11(1), 65-88.

Ring-Whalen, E., Dare, E., Roehrig, G., Titu, P., \& Crotty, E. (2018). From conception to curricula: The role of science, technology, engineering, and mathematics in integrated STEM units. International Journal of Education in Mathematics Science and Technology, 6(4), 343-362.

Sari, I. P., \& Syamsi, K. (2015). Pengembangan buku pelajaran tematik-integratif berbasis nilai karakter disiplin dan tanggung jawab di sekolah dasar. Jurnal Prima Edukasia, 3(1), 73-83.

Sarkar, S. (2012). The role of information and communication technology (ICT) in higher education for the 21 st century. Science, 1(1), 30-41.

Sherkat, D. E. (2011). Religion and Scientific Literacy in the U nited S tates. Social Science Quarterly, 92(5), 1134-1150.

Stronge, J. H. (2018). Qualities of effective teachers. ASCD.

Suprayogo, I. (2017). Membangun integrasi ilmu dan agama: Pengalaman UIN Maulana Malik Ibrahim Malang. proceeding IAIN Batusangkar, 1(1), $27-46$.

Wang, C. K., Wong, P. K., \& Lu, Q. (2001). Entrepreneurial intentions and tertiary education. Conference on Technological Entrepreneurship in the Emerging Regions of the New Millennium, 28-30.

Wastyanti, A. (2016). Pengembangan bahan ajar integrasi sains dengan agama berbasis multimedia di Madrasah Ibtidaiyah Negeri Malang 2 (PhD Thesis). Universitas Islam Negeri Maulana Malik Ibrahim.

Yunus, M. (2014). Integrasi Agama Dan Sains: Merespon Kelesuan Tradisi Ilmiah Di Ptai. Insania, 19(2), 284313. 